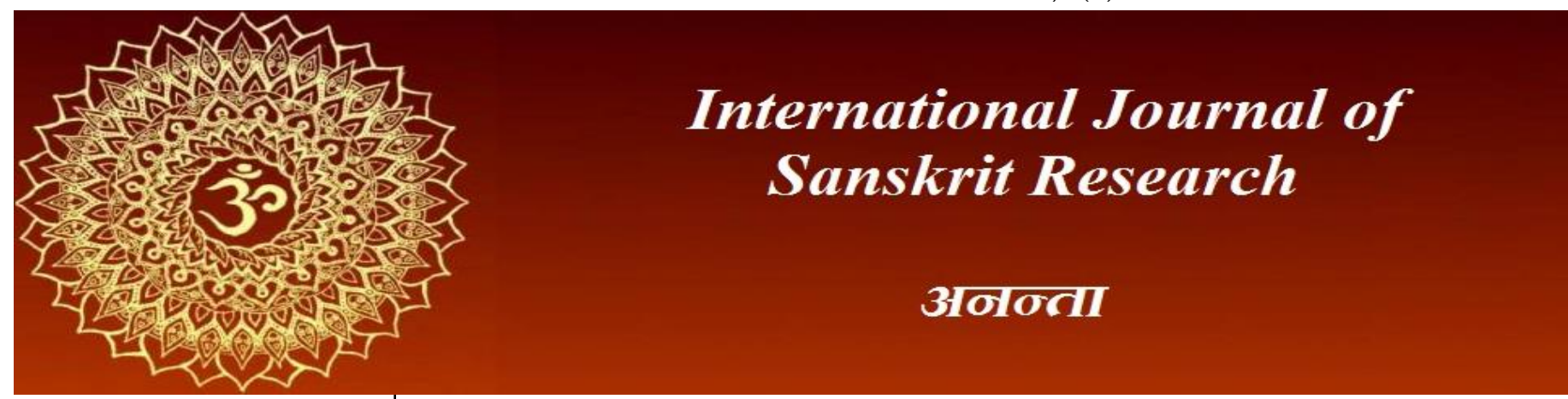

ISSN: 2394-7519

IJSR 2021; 7(5): 193-195

(C) 2021 IJSR

www.anantaajournal.com

Received: 07-07-2021

Accepted: 09-08-2021

Dr. VP Udaya Kumar

Associate Professor

Govt. Sanskrit College

Tripunithura, Kerala, India

Corresponding Author:

Dr. VP Udaya Kumar

Associate Professor

Govt. Sanskrit College

Tripunithura, Kerala, India

\section{Concept of katha and akhyayika in sanskrit literature}

\section{Dr. VP Udaya Kumar}

DOI: $\underline{\text { https://doi.org/10.22271/23947519.2021.v7.i5d.1499 }}$

Kavya or poetry in general in Sanskrit, is divided in to two दृश्य, what is to be seen and श्रव्य, what is to be heard. The Rūpakas, like नाटक fall under the first division while all other works like Mahakavyas are grouped under the second. Another principle of division is based on the form of language which is 'heard' indicating an oral tradition. According to it poetry is divided into three principal groups gadya (prose), padya (verse) and misra (the mixture of the two) ${ }^{[1]}$. Padya is predominant in Sanskrit, while gadya and misra compositions form only a small portion. Gadya is employed chiefly in the writings of plays, commentaries and other works of interpretation. Gadya is used very much as a medium of narration in kathas and ākhyāyikas.

The art of storytelling might have begun at a pre-historic time when language was emerging as the medium of communication. The popular tales which were transmitted orally are linked to the primitive narrative tradition. In Vedic literature also we can see many upākhyānas or narratives like शुनश्शेफोपाख्यानम् ${ }^{[2]}$, नचिकेतोपाख्यानम् ${ }^{[3]}$ etc. The Itihāsas and purānas are well nourished by a number of ākhyānas and upākhyānas; mostly in verse which were collections of popular stories. Besides this tradition we have a rich tradition of folk tale literature in prākrit, बृहत्कथा composed by Gunādhya sets up this tradition, which is translated into sanskri by क्षेमेमेन्द, सोमदेव and बुधस्वामी. The Buddhist Jatakakathā and the well known Pañcatantra contribute still another tradition.

While investigating whether there are any narrative theories in sanskrit, the two terms - kathā and ākhyāyikā - used by Sanskrit rhetoricians in their treatises strike our attention. The first and foremost Indian critic Bhamaha (600 AD) discusses the nature of kathā and ākhyāyikā in his काव्यालड्कार. Daņdin (700 AD) in काव्यादर्श and Rudrata (900 AD) in काव्यालड्कार., Bhoja (1100 AD) in शृड्गारप्रकाश Visvanādha (1400 A.D) in साहित्यदर्पण also discuss these two forms of narrative.

Kathā and ākhyāyikā are supposed to be two main brand the prose literature. आख्यायिका would be a narration of what actually happened. Kathā is story invented by the author.

\section{Ākhyāyikā}

The word ākhyāyikā is derived from the root khyā meaning tell'. The word ākhyana in the sense of narration of the story of kings and other celebrated personalities is very old, going back to Vedic times, as we have seen earlier.

The ākhyāyikā is in prose, though it may have a few introductory verses, sometimes two verses at the beginning of each of its chapters and rarely a verse elsewhere. This is generally divided into chapters called ucchvāsa or by any other synonym. This corresponds the division of mahākāvyas into cantos. Some critics seem to regard the ākhyāyikā practically as a mahākāvya, sharing the usual characteristics of them other than metre ${ }^{[4]}$.

It is not easy to get a clear idea of the form scope and content of the ākhyāyikā because few of them are extent and most of them remain in manuscript form. Dr. A.K. Warder opines that àkhyāyikas might have originated as a branch of Itihasa tradition and later to have assimilated into the kavya movement ${ }^{[5]}$. Kautilya in अर्थशास्त्र lists ākhyāyikas among the branches of Itihāsas ${ }^{[6]}$. 
The characteristic feature of ākhyāyikā' as a form of prose Kāvya, is that it is an account of what actually happened ${ }^{[7]}$. Bhamaha (600 A..D.) defines the ākhyāyikā as a prose composition with chapter divisions called ucchvāsas. The story being narrated by the hero himself, verses in certain metres like Vaktra and Aparavaktra are used occasionally to indicate future happenings. The narrative may be marked (अड्.कित:) by some special words indicating the intentions of the author. It's plot contains the abduction of a girl, a battle, frustration in love and then success of the hero. Bhāmaha says afterwards that a kathā may be either in Sanskrit or in Apabharamśa ${ }^{[8]}$. It is inferred that the theory accepted by Bhāmaha requires that an ākhyāyikā to be in Sanskrit.

Dandin (700 A.D) denies the validity in the distinction between kathā and ākhyāyikā ${ }^{[9]}$. He holds that these two are only two names for the same species of composition. He also points out that some of the description given by Bhāmaha had been infringed in practice, that were ākhyāyikās in which someone other than the hero narrates his actions, that metres other than Vaktra and Aparavaktra had been used. It is known that kathās are also divided in to chapters. The topics, abduction, battle etc. are found in mahākāvyas also.

Rudrata (900 A.D.) adds some further points, reflecting same developments in the conventions of an ākhyāyikā. It may begin with a salutation to gods or teachers and praise of poets. Then the author may give an account of how he came to compose his work, with his autobiography included. The chapters are like the cantos of a mahākāvya. Each may begin with two verses in the ārya metre, introducing the matter, whether present or past or lies in future. It may be resolved by a recitation of verses in various metres using the figures अन्योक्ति: and श्ठेष:, in the presence of the doubter when he provides an opportunity. Rudrata indicates that in general an ākhyāyikā should resemble a mahākāvya in construction ending with success, if there is a disaster for the hero he will eventually retrieve his fortunes ${ }^{[10]}$.

According to Ānandavardhana (900 A.D.) an ākhyāyikā should be composed using a diction of language that have moderate or long compounds. The beauty of an ākhyāyikā depends upon it ${ }^{[11]}$.

Bhoja (1100 A.D.) follows Bhāmaha but adds that an ākhyāyikā may be narrated either by the hero himself or by a follower of his. It should definitely be in Sanskrit prose. Bhoja also consider two minor types namely upākhyāna and ākhyāna. Upākhyāna is a minor akhyāna occurring in the midst of a big story. It is introduced to illustrate an idea and to enlighten someone. Ākhyāna is the dramatized form of upākhyāna. The discrition of Bhoja of these types makes this composition a variety of दृश्य class involving as it does song and gesture ${ }^{[12]}$.

Viśvanātha (1400 A.D.) the important writer on poetics defines ākhyāyikā as follows - an ākhyāyikā is like a kathā. It should include a genealogical account of the poet's family and also of other poets. Verses may occur in it at intervals. Chapters are called asvasas. These should contain introductory verses on the future incidents of the story. This definition does not help to clear the confusion, echoes the older ones ${ }^{[13]}$.

\section{Kathā}

Kathā or story is regarded as fictious narrative. It is generally written in prose. Bhāmaha notes that the kathā does not have the verses in Vaktra and Aparavaktra, the characteristics of an ākhyāyikā. It is not to be divided in to chapters ${ }^{[14]}$. From this Dr. A.K.Warder assumes that kathā may have a different organisation and perhaps that it is simply for private reading not for any kind of performance ${ }^{[15]}$. Bhāmaha also notes that a kathā is either in Sanskrit or in Apabhramsa. The kathā is narrated not by the hero but by others. According to Bhāmaha a noble person would not reveal his own qualities ${ }^{[16]}$. According to Dandin, as cited above, there is no difference between kathā and ākhyāyikāa ${ }^{[17]}$.

Rudrata gives a detailed account of the mahākathā, length story, which in principle is equivalent in scope to an epic ${ }^{[18]}$. The poet should open with a few verses paying respect to gods and describing the poet's family and containing the announcement that the poet is writing that story. Then the story begins in the same manner as the story in a mahākāvya with the only difference that the mahākathā shall deal with it in prose. Alliteration is favoured in the prose, together with a preponderance of short syllables. According to him this will give an impression of lightness and rapidity. Instead of beginning with the main story, the author may start with a subsidiary narrative and later introduce the main story to which it is necessarily connected. Rudrata's commentator Namisādhu names Bāņa's Kādambari, as a standard example of this construction. Rudrata says that the mahākathā may also be written in verse and prākrit. This may mean that there is no rigid rule regarding the language or metrical or prose medium for the kathā ${ }^{[19]}$. But Namisādhu interprets Rudrata as giving a ruling that if a kathā is in prakrit it should be in verse form [20]. This means that Sanskrit stories must be in prose.

Rudrata continues that the conclusion of a Kathā may be made by the description of the 'obtaining of a girl'. Namisādhu comments that the introductory verses in a mahākāvya may include the praise of the good men and blame of the scoundrels. If the conclusion is not the union with a girl it may be such as the winning a kingdom and so on ${ }^{[21]}$.

Afterwards Rudrata discusses the khandakathā - short story as form of minor kāvya (क्षुद्रकाव्यम्) ${ }^{[22]}$. He says that in a minor story, a happy hero comes to grief. There are many other characters in the story like brahmanas, traders and servants. The rasa would be प्रवरशृड्गारः or करुण: or प्रथमानुराग: all of course of the vipralamba aspect. Everything ends with the happiness of the hero ${ }^{[23]}$.

Commenting on short stories Namisādhu notes that the parikathā presumably as a form of minor kavyā, which is mostly in verse and is condensation of a narrative ${ }^{[24]}$.

According to Bhoja there is no rule that a kathā should be in Sanskrit alone and it could be in any language. So also a kathā could be in verse. There is no rule that it should be in prose. अनियतभाषा and अनियतजातिः ${ }^{255} 25$ (i.e. is not restrained by languages and genres).

Visvanatha says that in a kathā a charming plot is composed prose, which is interspersed with stanzas in the ārya, vaktra and aparavaktrā metres. In the beginning there should be a salutation a deity, a description of the nature of villains ${ }^{[26]}$.

The kathā and ākhyāyikā shares the common characteristics of the kāvyas such as the free usages of figures of speech, the practice of long descriptions and an overall organisation with reference to the theory of rasa and the purpose of kāvya.

Thus, Sanskrit rhetoricians discuss the characteristics features of kathā and ākhyāyikā in detail. The definitions given by them are vague in many places. There are many controversies in their views. They only give the definitions not cite the examples. Namisādhu was the first critic, who makes such an effort. But he neither analysed the characteristics of the texts nor gave logical reason for his assumption. 
Dandin remarks that no hard and fast line of demarcation call be drawn between the two classes of works and hence kathā and ākhyāyikā are but names to same species of prose composition.

All other ālankarikas take kathā and akhyāyikā as distinct literary forms. The differentiating features taken by Bhāmaha and others are worthy of consideration. The metres Vaktra and Aparavaktra are used in ākhyāyikā to indicate future events. According to Dr. A.K. Warder these metres are developed from the Vedic metre अनुष्टुप् ${ }^{[27]}$. These are seen used in Mahābhārata and other works to narrate the story. In kathā the metre ārya is used to indicate future events, which had been used in prākrit dialects to narrate the story ${ }^{[28]}$.

Moreover the ākhyāyikā should be in Sanskrit while kathā may either be in Sanskrit or in prakrit. From this we can assume that kathā and ākhyāyikā represents two distinct tradition i.e. kathā might have developed from folk tradition and ākhyāyikā from Vedic tradition.

\section{Conclusion}

In the above discussions of Sanskrit rhetoricians, it is clear that an effort is made by them towards theory of narration in the fiction and biographical accounts. Thus questions like who is the narrator, whether he is the hero or another character? What is the subject of narration and so on are raised. Although the answers given are not the best ones, the attempt to differentiate kathā and ākhyāyikā narratological premises are clearly a painter of the narratological orientation of those thoughts.

\section{Reference}

1. Dandin, काव्यादर्श:, Bhandarkar Oriental Research Institute, Pune, 1970, P13

2. ऐतरेयब्राह्मणम,, Thara Publications, Varanasi, VII-3

3. Vide कठोपनिषद्, Gita Press, Gorakhpur, 1995, I

4. Vide Rudrata, काव्यालड्कारम्, Motilal Banarsidas, New Delhi, 1980, XVI

5. Indian Kavya Literature, Motilal Banarsidas, New Delhi, 1989, Vol. I, P 182.

6. अर्थशास्त्रम, Comm. Vacaspali Gaurola, Chaukhambha Sanskrit Pratishthan, Varanasi. 1995, P 110.

7. Bhamaha, काव्यालङ्कारम, Naganatha Sastri P V, Ed. MLBD, New Delhi, 1991, I 28,29

8. Ibid, 40

9. Vide, काव्यादर्श: I, 24-28

10. Vide Rudrata, काव्यालड्कारम,, XVI, 23,24

11. ध्वन्यालोक:, Ānandavardhana, Chaukhambha Sanskrit Series, Varanasi. 1940, P 326.

12. Bhoja’s Śrngāraprakasa, Raghavan V Ed, Punarvasu, Madras, 1978, 427

13. Sahityadarpana of Visvanatha, Cohamani Dahal Ed, Chaukhambha Vidyabhavan, Varanasi, 1990, VI

14. Kavyalankara, I, 25-29

15. Indian Kavya Literature, Vol. I, 182

16. Kavyalankara 25-29

17. Kavyadarsa, 29

18. Kavyalankara, XVI

19. Ibid, 20-24

20. Ibid.

21. Ibid.

22. Ibid.

23. Ibid.
24. Ibid.

25. Bhoja's Śrngāraprakasa, 597

26. Sahityadarpana of Visvanatha, VI

27. Indian Kavya Literature, Vol. II, 20

28. Ibid, 54.

29. Dhvanyaloka of Anandavardhana, Pattabhiramasastri Ed. Chaukhambha Sanskrit Series, Varanasi, 1940.

30. Kavyalankara of Bhamaha Nagnatha Sastri Ed. Motilala Banarsidas, New Delhi, 1991.

31. Brihadaranyakopanishad with Sankarabhashya, Gita Press, Gorakhpur, 1996.

32. Kavyadarsa of Dandin, Pandit Rangacharya Reddi Sastri Ed. Bhandarkar Oriental Research Institute, Poona, 1970

33. Sringaraprakasha of Bhoja, Raghavan V Ed. Punarvasu Publications, Madras, 1978.

34. Kavyalankara of Rudrata, Jagannatha Pathak Ed. Motilal Banarsidas, New Delhi, 1980.

35. Sahityadarpana of Visvanatha, Lohamani Dahal Commentator, Chaukhambha Vidyabhavan, Varanasi, 1990

36. Indian Kavya Literature, Warder A K, Vols I - VII, Motilal Banarsidas, New Delhi 